\title{
PROGRESSIVE LAW REVEALED: A LEGAL PHILOSOPHICAL OVERVIEW
}

\author{
Erlyn Indarti \\ Faculty of Law, Diponegoro University \\ erlyn@ymail.com
}

\begin{abstract}
Progressivism is in essence the principles, beliefs, or practices of progressives, i.e. ones believing in moderate social and political progressin the human condition by means of governmental action. Today's progressives still fail to offer a coherent account of their core philosophy. They are identified more often by 'what it is not' than by 'what it is'. Progressive law requires the state toembrace a boundless function and use its powerto tell people what they must and must not doso as to allow them to get hold of their desired affluence. This concept is embodied in the legal principle Malum Prohibitum. Legal philosophical overview reveals that with thisprinciple progressive law may have the potential to manufacture a system of laws that excessively empowers the state so that liberty is crushed and the light of a free society is replaced with the darkness of tyranny.
\end{abstract}

Keywords : progressivism, progressive law, legal philosophy

\section{Introduction}

Talks about progressivism - which actually started in the last few decades of the 19th century - have recently re-emerged. Not infrequently these discussionsburst into relentless tugof-war between various opposing camps. ${ }^{1}$ What is not realized is that this contention is really unnecessary; for those discoursesin fact take place in different levels of study extending from practical, scientific, theoretical, up to philosophical. ${ }^{2}$

The currentidea of progressivism actually emerged from the immensesocial changesinduced by industrializationin the Western worldin the late 19th century. This vision of progressivism is basically more political. It predominantly came out of the view that progress was being suppressed by extensive economic disparity between the rich and the poor. It also stemmed from thenotion that progress was being held back by minimally regulated laissezfairecapitalism with monopolistic corporations. In addition, it derived from the opinion that progress was restrained by severe and often cruel conflict between workers and capitalists. This was when the concept of progressivism ripened to cope with these problems. Since then

1 See Michael Greshen, Why Progressives Should Support Donald Trump. (North Charleston, SC: CreateSpace Independent Publishing Platform, 2015). See also The Nation. October 5, 2016. Why Progressives Should Vote for Hillary Clinton.

2 Seee Cass R. Sunstein, "A New Progressivism”, The University of Chicago, The Chicago Working Paper Series Index: http://www.law.uchicago.edu/Lawecon/index.html., (May, 2005). 
progressivism has been perceived from various points of view and thus its meanings havevaried over time. $^{3}$

This inevitably confronts academics as well as practitioners in a series of ambiguities, particularly when such exchanges are placed within the legal context. In this regard, unequivocal foundation of thought that stratally, connectionally, sequentially, and integrally include those layers of levels of study is therefore called for. ${ }^{4}$ With this, the relation between progressivism and law - in its form as progressive law_can be studied in more detail, so that it can be differentiated, sorted, and placed at the proper level of study.

The foundation of thought mentioned above is philosophical study, primarily legal philosophical overview in its broad sense. Legal philosophy is a subject in law, and therefore concerns itself firstly with law. ${ }^{5}$ A legal philosophical overview has all the potential to trace level by level - the understanding of progressivism and law, includingtheir interrelation, in accordance with the paradigm within which the two meanings are contained. Through legal philosophical overview existing legal knowledge is hoped to be modified, horizons of legal knowledge is expected to be continuously expanded, and new legal knowledge is believed to be initiated. $^{6}$

\section{Method}

The present article ontologically delineates the contour of progressive law, an interweaving union of progressivism and law. In doing so, this article hermeneutically and dialectically employs the methodological principles of philosophical research, mainlyby way of literature review. The application of philosophical research methodologyowes to the fact that legal philosophal overview is essentially fraction of philosophy. ${ }^{7}$ Through this methodology, the philosophical scheme of progressive law fundamentals can be revealed. Such endeavor is expected to - in due course - contribute to wide-ranging understanding of intertwining rapport of progressivism and law.

3 Walter Nugent, Progressivism: A Very Short Introduction (Oxford: Oxford University Press, 2010), 2.

4 Erlyn Indarti, Filsafat Ilmu : Suatu Telaah Paradigmatik, Bahan Kuliah Program Doktor Ilmu Hukum Undip.

5 Erlyn Indarti. “Bridging The Gaps : A Paradigmatic Insight Into Philosophy of Law, ” Diponegoro Law Review Vol. 01 No. 01 (October 2016): 2

6 Erlyn Indarti, Diskresi dan Paradigma: Sebuah Telaah Filsafat Hukum (Semarang: Badan Penerbit Universitas Diponegoro).

7 Sudarto, Metodologi Penelitian Filsafat (Jakarta: PT RajaGrafindo Persada, 2007). 


\section{Result and Discussion}

In the last decade of the nineteenth century and the first decades of the twentieth, a dynamic, complex social reform movement known as Progressivism swept through the middle and upper sectors of American society. The Progressives were a varied lot, and they had a varied political and social agenda. But among their chief aims were the elimination of corruption from politics, the introduction of efficiency and scientific technique into the governmental process, the uplifting of the underprivileged, and the assimilation into society's mainstream of the immigrant masses who were then pouring into the United States in record numbers. The whole Progressive program rested solidly on two fundamental principles: faith in the perfectibility of man, and implicit trust in the state's ability to promote individual well-being. The major reforms in the treatment of criminal offenders - probation, parole, and the juvenile court-that were either introduced or came into vogue during this era may be seen as manifestations of the Progressive spirit. $^{8}$

\subsection{Progress, Progressive, and Progressivism}

Progressivism is in essence the principles, beliefs, or practices of 'progressives', i.e. ones believing in moderate political change and especially social improvement by governmental action. ${ }^{9}$ Progressives also generally refers to believers in the possibility and desirability of 'progress', i.e. of a moral and social improvement in the human condition. This view signifies specific optimism about human nature. ${ }^{10}$ When capitalizedit is understood as the political and economic doctrines advocated by the 'Progressives'. ${ }^{11}$ In fact, Progressives with capital P denote political interests, groups, or parties searching for achievement of the above mentioned progress by getting rid of institutions which block it and advocating measures which they trust will support it.In thismeaning, left wing parties, liberals, radicals, socialists,communists, etc.- that is before they come to power-, can accordingly be counted as Progressives. ${ }^{12}$

8 http://law.jrank.org/pages/880/Criminal-Law-Reform-Historical-Development-in-United-States-Progressivismits-fruits.html">Criminal Law Reform: Historical Development in the United States - Progressivism And Its Fruits

9 Merriem-Webster English Dictionary. Retrieved 25 March 2018.https://www.merriamwebster.com/dictionary/progressivism.

10 J. B. Bury, The Idea of Progress. (London and N.Y., 1920) in Alan Bullock and Oliver Stallybrass, The Fontana Dictionary of Modern Thought, (London: Fontana/Collins, 1977).

${ }^{11}$ Merriem-Webster English Dictionary. Retrieved 25 March 2018.

12 Alan Bullock and Oliver Stallybrass, The Fontana Dictionary of Modern Thought (London: Fontana/Collins, 1977). 
The word 'progress'itself is etymologically Latin, a combination ofpro and gradi. Literally, it means 'to walk forward'. ${ }^{13}$ According to Immanuel Kant, progress is essentially a development from barbarism on the way to civilization. As fas as political change is concerned, Marquis de Condorcet puts forward a philosophical foresight that progress would implicate the abolition of bondage, the upsurgeof reading and writing proficiency, the decrease of sexual imbalances, improvement of prisonconditions, and the reduction of impoverishment. ${ }^{14}$ In promoting the idea of progress, the proponents of classical liberalism are of the opinion that 'modernity' or 'modernization' is thesignificantactualization of progress. They mantain that immediate economic and social modernization should be called for so as to to eliminate distinctive obstructions to free markets and free movements of people. ${ }^{15} \mathrm{In}$ short, progress as it is currently understood is primarily anenlightenment concept. ${ }^{16}$

As for Karl Marx, progress lays in the development of the forces of production and their eventual use, after revolutionary struggle, in the satisfaction of human need rather than private accumulation. Max Weber, in the mean time, sees progress somewhat more ambivalently, it lay in the rationalization of economic, organizational, legal and scientific life. Adding to this already multifaceted view of progress, Emile Durkheim observes progress as the enhanced possibilities for individual freedom in forms of organic solidarity. Later in early 90s, Progress is comprehended as a movement towards a desired objective; in other words it is a development or advance, which is favourably regarded. ${ }^{17}$

Regarding to the above exposure, the word 'reaction' and 'reactionary' are generally considered as the opposite of 'progress' and 'progressive'. Nevertheless, not many people would be straight forward enough to portray themselves as 'reactionary'. This is due to the fact that the term is most commonly regarded as having negative connotation. The word 'reactionary' is applied mostly by the left whenever they refer to the resistance of traditional institutions to their right-wing radicalism. ${ }^{18}$ What 'progress' is and what 'reaction' is depend very much on where you start and where you want to go. If equality is the goal — as many self-described progressives say it is - then any progress toward equality should be considered, well, progress. If that is the case, communism may be regarded as the most progressive cause of all. Communism was

\footnotetext{
13 Sidney B. Fay, "The Idea of Progress" in Jack Russell Weinstein (1947).

14 Robert Nisbet. History of the Idea of Progress. (New York: Basic Books, 1980).

15 Joyce Appleby; Lynn Hunt \& Margaret Jacob, Telling the Truth about History (1995).

16 Jack Russell Weinstein, "On the Meaning of the Term Progressive: A Philosophical Investigation”, William Mitchell Law Review Vol. 33 (1996):1.

17 David Jary and Julia Jary, Collins Dictionary of Sociology (Glasgow: HarperCollinsPublisher, 1991)

18 Alan Bullock and Oliver Stallybrass (1977).
} 
undoubtedly considered as such by many intellectuals in the past. In fact Karl Marx saw history as a sort of march of progress: from primitive communism to slave society to feudalism to mercantilism to capitalism to socialism and finally to communism. In this case, it could be said that the Soviet Union definitelyhad its fair share of reactionaries and counter-revolutionaries. ${ }^{19}$

Meanwhile, the term 'progressive' is the most likely candidate to fill the role of the word 'liberal'since it is considered by many to be political suicide.Progressive is therefore apllied precisely because it sounds more centrist to the audience thanliberal. ${ }^{20}$ Yet the term progressive is certainlynot straightforward. In the case of the United States of America, history reveals itself that there is actually no one set of principles or single ideologythat unifies those who fall under the category of progressives. Today, American Progressives are on the political left; whereas the Progressive Conservative Party in Canada, for instance, is right of center.But how far left on the spectrum they fall is uncertain. Being on the political left, American progressives tend not to venture to the extreme that they are having an affair with theright. Hence, Progressives are notrevolutionaries. They seek change, not social upheaval, althoughsometimes this change is significant and can be traumatic. ${ }^{21}$

One class of Progressivism is what is refered to as 'social justice Progressivism'. Social justice Progressives requireactivists to prioritize the effort to provide for the common welfare. They argue that real democracy must operate from a sense of social morality that will foster the greater good of all rather than protect those with wealth and power. ${ }^{22}$ Social justice Progressivism confronts two problems to securing a democracy based on social morality. They want several basic premises that currently structure the country to bereassessed. What is interesting is that social justice Progressivism has so far been promoted largely by women who in truth lack official political power.Social justice Progressives seek national legislation to protect consumers from the pernicious effects of industrial production outside of their immediate control. They set sights on a ban on child labor and protections for children's health and education. $^{23}$

Another kind is what is known as 'political Progressivism'. This is actually a structuralinstrumental approach to reform the mechanisms and exercise of politics to break the hold of

19 Andrew Syrios, “A Brief History of Progressivism”. Mises Daily Articles. Mises Institute Austrian Economis, Freedom, and Peace. July 22nd (2014)

20 Jack Russell Weinstein, "Democrats Must Stop Apologizing for Liberal Beliefs'. The Grand Forks Herald (N.D.), Nov. 13. (http://www.und.nodak.edu/instruct/weinstei/ gfheraldnov13.htm), (2003)

21 Jack Russell Weinstein (2006).

22 Jane Addams, Democracy and Social Ethics (New York: Macmillan, 1902)

${ }^{23}$ Maureen A. Flanagan, "Progressives and Progressivism in an Era of Reform". Oxford Research Encyclopedias. Online Publication Date: Aug (2016). 
political parties. Its adherents strive for a well-ordered government run by experts to undercut a political patronage system that favors trading votes for services. Political Progressives believe that such reforms would enhance democracy.The political Progressives attack patronage politics that fills administrative offices with faithful party supporters, awards service franchises to private business, and solicits bribes in return for contracts. Political Progressives propose shifting to merit-based government by experts provided by theoretically nonpartisan appointed commissions that would apply businesslike expertise and fiscal efficiency to government.These Progressives propose a form of 'good government by experts' and argue that only the technological expertise of professional engineers and professional bureaucrats could design rational and economically efficient ordinances for solving the country's problems. Interestingly, political Progressives aremade up mainly by men organized into, among other things, federations, clubs, reform leagues, and research bureaus. ${ }^{24}$

Still other brand is what is called 'economic Progressivism'. Economic Progressives identify unregulated corporate monopoly capitalism as a primary source of the country's problems. ${ }^{25}$ They put forwarda new regulatory state to mitigate the worst aspects of the system. They are of the opinion that reforming the banking and currency systems, pursuing some measure of antitrust (antimonopoly) legislation, shifting from a largely laissez-faire economy, and moderately restructuring property relations will produce government in the public interest.One sub class of economic Progressivism is what is identified as antimonopoly Progressivism. These progressives have need of rethinking the relationship between business and government, introducing new legislation, and modifying a legal system that consistently sides with business. Congress and the presidency have to take leadership roles, but below them were Progressive groups. They believe collusion between a small number of capitalist industrialists and politicians has the potential to badly damage democracy. They especially fear that the system threaten to lead to class warfare. ${ }^{26}$

\subsection{Progressive, Governance, and Science: What-It-Is-Not rather than What-It-Is}

It seems that Progressivesendeavour to make sure that the democratic processes of justice and equality take place. They also strive to achieve a modern Progressive future, not bybringing down capitalism, but by mufflingcapitalism's least wantedsurfeit. They promisea more

\footnotetext{
24 Ibid.

25 Martin J. Sklar, The Corporate Reconstruction of American Capitalism 1890-1916 (Cambridge, U.K.: Cambridge University Press, 1988)

26 Maureen A. Flanagan (2016).
} 
cooperative, democratic society in place of an individualistic, competitive one. They want to introducean economic-oriented regulation so as to bring a measure of social justice for all people, to eliminate political corruption, and to rebalance the relationship among business, labor, and consumers. ${ }^{27} \mathrm{As}$ it has been mentioned before, in making the effort to achieve these objectives,Progressives evidently turn to government. This turn is then followed by theirlaying the foundation for an increasingly powerful state. ${ }^{28}$

Yes. Progressives are sturdily attached to the government. Theytend to applaudstate intervention. Yet, they also believe in citizenparticipation and grassroots action. Perhaps more than any otherpolitical classification, progressives hold onto the ideal of directdemocracy. They heartily embrace the tensions between whatis called 'negative' and 'positive' freedoms, or freedomfrom and freedom to, respectively, where a commitment to positive freedom is deemed as a dangerous form of Hegelian proto-fascism. ${ }^{29}$

In America, as the nation was struggling to cope with a wide range of social, economic, and cultural changes during the last two decades of the nineteenth century and the first two decades of the twentieth century, the - social-turning-into-political-idea of progressivism was conceived and hence a reform movement wasinitiated. In making the effort to perceive the nature of the nation's problems as well as to resolve them, progressives believed that government at all levels must play an active role in reform. They sought legislation to broaden the state's power to curb the excesses of large-scale corporate capitalism and to address the host of inequities. ${ }^{30}$ In this regard, the American Progressives believed that 'science' and 'efficiency' should be the watchwords of reform, and they developed an ambitious program extending from national parks to kindergartens, and from town planning to 'scientific motherhood'. 31

Progressives aim to apply scientific principles to manage economic, social, and political institutions. It is believed that this would end social conflicts and promote economic order. It is understandable then if progressivism is also understood as the support for or advocacy of social reform. ${ }^{32}$ Care should be taken, though, progressivism should not be confused with socialism. Although a minority of Progressives embraced socialism. ${ }^{33}$ In relation to this, and as already

\footnotetext{
27 Maureen A. Flanagan, America Reformed: Progressives and Progressivisms, 1890s-1920s, (New York: Oxford University Press, 2007)

28 Maureen A. Flanagan (2016).

29 Isaiah Berlin, "Two Concepts of Liberty" in Henry Hardy and Roger Hausheer (eds.). The Proper Study of Mankind (1998).

30 The Oxford Companion to the Supreme Court of the United States (2nd ed.) (2005)

31 The Oxford Companion to Australian History (2003)

32 Oxford English Dictionary.https://en.oxforddictionaries.com/definition/progressivism.Retrieved 25 March 2018.

33 Oxford Encyclopedia of the Modern World (2008)
} 
indicated above, progressivism isphilosophically rootedin the idea of 'progress'. This idea affirmsthat improvementin science, technology, economic development, and social organization are fundamentalto the advancementof the physical and mental stateof mankind. ${ }^{34}$ Progress is also profoundly understood as the result of social development, involving the enhancement of scientific and technological knowledge, economic productivity and the complexity of social organization. ${ }^{35}$

What it means to be progressive, at least historically, is very much amess. While presentday progressive attitudes seem, at the first glimpse, to be more focused, today's progressives still fail to offer a coherent account of their core philosophy. In other word, the term progressive remains undefined. This lack of definition is only further complicated by progressivism's de facto role as the opposition to the contemporary mainstream. Consequently, progressivism is identified more often by 'what it is not' than by 'what it is'. ${ }^{36}$ For instance, contemporary progressives demand for institutional experimentalism to counter the 'rigid' ideological grids of past progressivism that overlook the intricacy of the people's life still gives the big question mark on the understanding of the term 'rigid'; ${ }^{37}$ even though it gives the impression to refer to the characteristic of the left, i.e. the unwillingness to compromise. ${ }^{38}$

The already long list of the above 'what it is not' goes even further when it comes to legalframework. Progressives distinguish their methodology fromthe previously in existence and operation 'traditional jurisprudence' and 'mainstream legal thought', hoping to place theirsat odds withthe methodology of legal adjudication and research.Still with noclear definition of 'what progressive is', they offer the following inventory of 'what it is not'. First, they take on the idealized decision-making process thatpresides overthe establishment and practice of law. Second, they demanddemocratic reorganization and restructuring to allow for more popular participation inpolitical decision making, particularly in those decisions that affectthe courts. Third, they denythe ideathat either the law or thestate are 'neutral, value-free arbiters, independent of andunaffected by social and economic relations, political forces andcultural phenomena.' Fourth, they necessitatea reassessmentof thelegitimization function for law, arguing that thoughthe law's ultimatemechanism for control and enforcement is institutional, it violently

\footnotetext{
${ }^{34}$ Harold Mah, Enlightenment Phantasies: Cultural Identity in France and Germany, 1750-1914 (New York: Cornell University, 2003)

35 David Jary and Julia Jary (1991)

36 Jack Russell Weinstein (2006)

37 Roberto Mangabeira Unger and Cornel West, "Progressive Politics and WhatLies Ahead" The Nation. Nov. 23. (1998)

38 Jack Russell Weinstein (2006)
} 
protects the dominant system of social and power relationsagainst political and ideological as well as physical challenges. ${ }^{39}$

The description as shown above reveals severalwhat-it-is-not themes that have been conveyedfrom theearlier twentieth-century progressives: the passion for reform, thecall for a more direct democracy, the appeal of populism, and anunderstanding of the political and legal process as the adjudicationof disputes among particular competing groups. To these assortment of themes, the description also introduces two newsubjects: the rejection of abstract contextless procedure and the attack on thefalse claim of political neutrality that characterizeslegal and political procedure. ${ }^{40}$ These last two topics may actually be seen as the extensions of theolder concerns. First, a political processthat passes judgmentto conflictinggroups cannot be neutral; it must observethe detailsofsituation.Moreover, any reformist movement cannot bepurely theoretical. It must look at real conditionsandconcludehow to modifyinstitutions from one shapeto another. ${ }^{41}$

\subsection{Progressive Law and the State: Malum Prohibitum}

Going through the last paragraphs of the above section, one could not help notice that connection between Progressives and law was already put forward. In relation to this, it is understandable if the sole legitimate purpose of the state is commonly believed to be upholding justice in order to protect the indisputable rights of the people to be safe in the pleasureof their life, liberty, and property. This purpose is fulfilled by means of limited role of the state to keep the people safe and free so that they could achieve whatever degree of prosperity their talent and industry could lead to. A series of statutes, legal precedents, and government regulations altogether outline such role. Against the above perspective is a more positive orientation of law and justice epitomized by progressive legal thought. In this regard, progressive law requires the state to abandon its restricted function and embrace a boundless one so as to allow people to get hold of their desiredaffluence. It can be said, therefore, progressive law rests on the presupposition that the state has the power to tell their citizens what they must-as well as must not- do. Unfortunately, this assumption is in fact the very essence of tyranny. ${ }^{42}$

For progressives, it is imperative to seeproblems with how money and moneyed interests exert anexcessive influence upon, for example, the outcome of elections and the direction of

\footnotetext{
39 David Kairys, "Introduction" in David Kairys (ed.). Introduction to The Politics of Law: A Progressive Critique (rev. ed.).

40 Ibid.

41 Jack Russell Weinstein (2006).

42 See Mark Hendrickson,'The Pandora's Box Of Progressivism: Positive Law', Forbes, May 30 (2013)
} 
policy. They notice that such an influence is occasionally approved by the judiciary as if the ability of money to 'talk' - by which the voices of the few are magnified and the voices of the many are crowded out - is regarded as as a principle rather than a wrong. ${ }^{43}$ This portrayal resonates some of the progressive contention of the early twentieth century's gloomy political climate. In those days, politics were sadly subject to the corrupting influence of money and big business; and individual non-moneyed voices in the political process were inevitably exposed to unfair exclusion. This is when progressives once again necessitated more regulation and more grassroots participation. ${ }^{44}$

As far as progressives' contribution in the area of the court of justice is concerned, of all criminal justice reforms promoted by progressives, the most emblematic was the juvenile court. Article 1 Number 2 The Juveniles Criminal Justice System Act Number 11, 2012 states that "The Juveniles involved within the law is the juveniles who have any conflict in the law, so they have to face the criminal justice system. Juveniles age in this regulation is 12 years old but not 18 years old yet who were accused have done any offence". According to this regulation the child who allows get into criminal justice process in that age limits could be responsibled for any offence that she /he had done ${ }^{45}$ Progressivism was a child-centered movement, and child welfare was a major focus of Progressive activity. Before the advent of juvenile court, jurisdictions had often devised ways of sparing youthful offenders the full rigors of the legal process, but, as has been pointed out, what was missing was the conception that a young person who ran afoul of the law was to be dealt with from the outset 'not as a criminal, but as a person needing care, education and protection'. The court, in general, was to be thrust into the role of parens patriae, a role not unknown to equity courts. The juvenile court was to operate under relatively relaxed, nonadversarial procedures, with the role of counsel reduced, and its role was to be seen as remedial rather than punitive. The question before the court would not be whether the accused juvenile was guilty of a crime, but whether he was 'delinquent' and thus in need of the state's care and education. ${ }^{46}$

Nevertheless, such contribution is overshadowed by the fact that progressivism by its nature lacks the commitment to the rule of law. As a matter of fact, in the American case, the

\footnotetext{
43 Roberto Mangabeira Unger and Cornel West (1998)

44 Jack Russell Weinstein (2006)

45 Umi Rozah, "The Parental Responsibility Concept in Replacing Criminal Responsibility of Child to Parent (The Study of Indonesian Tribes Culture in Lampung and Aga Balinese Tribe)", Diponegoro Law Review, October 2017, Volume 02 (02): 342.

${ }^{46} \mathrm{http} / / /$ law.jrank.org/pages/880/Criminal-Law-Reform-Historical-Development-in-United-States-Progressivismits-fruits.html">Criminal Law Reform: Historical Development in the United States - Progressivism And Its Fruits
} 
history of progressivism demonstrates that it undyinglyharms the constitutional fundamentals of the country. So injured was the United states during the most recent presidential election that it suffered from the fevers of progressivism more than any time since the 1960s. The election set in opposition a candidate lawless by virtue of temperament, i.e. the 'reactionary', against one lawless by virtue of ideology and emboldened by the spirit of the times, i.e the 'progressive'. It can be said that the rule of law is under threat. As it is historically known, at the heart of progressivism is the believe that federalism and separation of powers are obstacles to the progressive social engineering.For that reason, progressivism has relentlessly tried to discard these restraints so as to make the executive ever more powerful in domestic affairs. By so doing progressivismessentially departs from - thus devalues the formal rules laid down by - the Constitution and gives the impression that they celebrate law and norm breaking. ${ }^{47}$

Care should be taken that the very essence of Progressivism is the belief that the State and its agents must come to a decision about what is right and what is wrong. This belief is embodied in the legal principle Malum Prohibitum ${ }^{48}$ or 'that which is wrong because it is prohibited'. ${ }^{49}$ All Progressives - Right or Left — have faith in these things and can neverenvisage a world without such doctrines. On the other hand, there is this opposinglegal idea which is established on the conviction that some things are unlawful in and of themselves, and that each person acknowledges the incorrectness in his or herdeeds. This idea is exemplified in the legal tenetMalum in $\mathrm{Se}^{50}$ or 'that which is wrong in itself'. ${ }^{51}$ Homicide, manslaughter,assault, rape, robbery, burglery, theft, lying in a legal proceeding, and other such actions have been unlawful all through history in almost every culture. That certain individuals have managed to avoid arrest and punishment or thatsome persons - given state privilege - are able to do these things and not be sanctioned does not make those unlawful actions 'legal' in the minds of most people. ${ }^{52}$

Unluckily, the legal principle Malum Prohibitum hastaken the place of Malum in Se as the guiding legal force in present-day criminal laws. Those many inmatesin prisonsand those many millions more defendants and suspects in the criminal justice system, are there because they allegedly violated those 'laws' based upon Malum Prohibitum. In this regard, we have to

\footnotetext{
47 John O. McGinnis, "Progressivism Is a Long-Term Threat to the Rule of Law", Library of Law and Liberty. July 18 (2016).

48 William L. Anderson, Malum Prohibitum: The Evil Legal Language of Progressivism. LewRockwell.com. Jan. $21(2013)$.

49 https://law.stackexchange.com/questions/113/what-are-the-differences-between-malum-in-se-and-malumprohibitum-laws

50 William L. Anderson (2013)

51 https://law.stackexchange.com/questions/113/what-are-the-differences-between-malum-in-se-and-malumprohibitum-laws

52 William L. Anderson (2013)
} 
understand that the laws and punishments that flow from this doctrine are severe and arbitrary and have turned justicesystem into a sort of trap of injustice. ${ }^{53}$

The legal problems depicted above are not merelybrought about by those Progressives on the Left, no matter how hypocritical they might be. The law-and-order Progressives of the Right are just as bad because they genuinely believethat Malum Prohibitum is the soul of the Good Society and that rules are made for a good reason. In the end, it should be taken into account that Progressive law may have the potential tomanufacturea system of laws that excessively empowers the state so that liberty is crushed and the light of a free society is replaced with the darkness of tyranny. ${ }^{54}$ And this, regrettably, is the kind of legal conundrum that the populaces have to face on daily basis nowadays.

\section{Conclusion}

Progressivism is in essence the principles, beliefs, or practices of 'progressives', i.e. ones believing in moderate political change and especially social improvement by governmental action. Progressives generally refers to believers in the possibility and desirability of 'progress', i.e. of a moral and social improvement in the human condition. They trust that government at all levels must play an active role in reform by applying scientific principles to manage economic, social, and political institutions.

Sadly, today's progressives still fail to offer a coherent account of their core philosophy. In other word, the term progressive remains undefined. This lack of definition is only further complicated by progressivism's de facto role as the opposition to the contemporary mainstream. Consequently, progressivism is identified more often by 'what it is not' than by 'what it is'.

Progressives offer the following inventory of 'what it is not' within the legalframework: taking on the idealized decision-making process in the establishment and practice of law;demandingdemocratic reorganization and restructuring to allow for more popular participation particularly in those decisions that affect the courts; denying the idea that either the law or the state are neutral and independent of social and economic relations, political forces andcultural phenomena; andnecessitating a reassessment of thelegitimization function for law.

Progressive law requires the state to abandon its restricted function and embrace a boundless one so as to allow people to get hold of their desiredaffluence. Itrests on the presupposition that the state has the power to tell its citizens what they must-as well as must

\footnotetext{
53 Ibid.

54 Ibid.
} 
not - do which is embodied in the legal principle Malum Prohibitum. Progressive law may have the potential to manufacture a system of laws that excessively empowers the state so that liberty is crushed and the light of a free society is replaced with the darkness of tyranny.

\section{References}

Addams, Jane. (1902). Democracy and Social Ethics. New York: Macmillan.

Anderson, William L. (2013). Malum Prohibitum: The Evil Legal Language of Progressivism. LewRockwell.com. Jan. 21.

Appleby, Joyce; Lynn Hunt \& Margaret Jacob. (1995). Telling the Truth about History.

Berlin, Isaiah. (1998). 'Two Concepts of Liberty' in Henry Hardy and Roger Hausheer (eds.). The Proper Study of Mankind.

Bullock, Alan and Stallybrass, Oliver. (1977). The Fontana Dictionary of Modern Thought. London: Fontana/Collins.

Bury, J. B. (1920). The Idea of Progress. London and N.Y. in Alan Bullock and Oliver Stallybrass. (1977). The Fontana Dictionary of Modern Thought. London: Fontana/Collins.

Erlyn Indarti. (2016). Bridging The Gaps : A Paradigmatic Insight Into Philosophy of Law. Diponegoro Law Review, Volume 01, Number 01.

Fay, Sidney B. (1947). 'The Idea of Progress' in Jack Russell Weinstein. (2006)

Flanagan, Maureen A. (2007). America Reformed: Progressives and Progressivisms, 1890s1920s. New York: Oxford University Press.

Flanagan, Maureen A. (2016). 'Progressives and Progressivism in an Era of Reform'. Oxford Research Encyclopedias. Online Publication Date: Aug.

Greshen, Michael. (2015). Why Progressives Should Support Donald Trump. North Charleston, SC: CreateSpace Independent Publishing Platform.

Hendrickson, Mark. (2013). 'The Pandora's Box Of Progressivism: Positive Law'. Forbes. May 30.

http://law.jrank.org/pages/880/Criminal-Law-Reform-Historical-Development-in-United-StatesProgressivism-its-fruits.html">Criminal Law Reform: Historical Development in the United States - Progressivism And Its Fruits 
https://law.stackexchange.com/questions/113/what-are-the-differences-between-malum-in-seand-malum-prohibitum-laws

Indarti, Erlyn. (2010). Diskresi dan Paradigma: Sebuah Telaah Filsafat Hukum. Semarang: Badan Penerbit Univesitas Diponegoro. ISBN: 978.979.097.017.5

Indarti, Erlyn. (2017). Filsafat Ilmu : Suatu Telaah Paradigmatik. Bahan Kuliah. Program Doktor Ilmu Hukum. Undip

Jary, David and Jary, Julia. (1991). Collins Dictionary of Sociology. Glasgow: HarperCollinsPublisher.

Kairys, David. (1990). 'Introduction' in David Kairys (ed.). Introduction to The Politics of Law: A Progressive Critique (rev. ed.).

Mah, Harold. (2003). Enlightenment Phantasies: Cultural Identity in France and Germany, 1750-1914. Cornell University.

McGinnis, John O. (2016). 'Progressivism Is a Long-Term Threat to the Rule of Law'. Library of Law and Liberty. July 18.

Merriem-Webster English Dictionary. Retrieved 25 March 2018. https://www.merriamwebster.com/dictionary/progressivism.

Nisbet, Ribert. (1980). History of the Idea of Progress. New York: Basic Books.

Nugent, Walter. (2010). Progressivism: A Very Short Introduction. Oxford University Press. p. 2. ISBN9780195311068.

Oxford English Dictionary.https://en.oxforddictionaries.com/definition/progressivism.Retrieved 25 March 2018.

Oxford Encyclopedia of the Modern World. 2008.

Sklar, Martin J. (1988). The Corporate Reconstruction of American Capitalism 1890-1916. Cambridge, U.K.: Cambridge University Press.

Sudarto. (1997). Metodologi Penelitian Filsafat. Jakarta: PT RajaGrafindo Persada.

Sunstein, Cass R. (2005). A New Progressivism. The Universsity of Chicago. The Chicago Working Paper Series Index: http://www.law.uchicago.edu/Lawecon/index.html. May. 
Syrios, Andrew. (2014). 'A Brief History of Progressivism'. Mises Daily Articles. Mises Institute Austrian Economis, Freedom, and Peace. July 22nd.

The Nation. (2016). Why Progressives Should Vote for Hillary Clinton. October 5.

The Oxford Companion to the Supreme Court of the United States (2nd ed.). (2005).

The Oxford Companion to Australian History. (2003).

Umi Rozah. (2017) The Parental Responsibility Concept in Replacing Criminal Responsibility of Child to Parent (The Study of Indonesian Tribes Culture in Lampung and Aga Balinese Tribes ). Diponegoro Law Review, Volume 02, Number 02.

Unger, Roberto Mangabeira and West, Cornel. (1998). 'Progressive Politics and WhatLies Ahead'. The Nation. Nov. 23.

Weinstein, Jack Russell. (2003). 'Democrats Must Stop Apologizing for Liberal Beliefs'. The Grand Forks Herald (N.D.), Nov. 13. (http://www.und.nodak.edu/instruct/weinstei/ gfheraldnov13.htm)

Weinstein, Jack Russell. (2006). 'On the Meaning of the Term Progressive: A Philosophical Investigation'. William Mitchell Law Review. Vol. 33:1. 